\title{
A comparative study of ribotyping and arbitrarily primed polymerase chain reaction for investigation of hospital outbreaks of Acinetobacter baumannii infection
}

\author{
J. VILA, A. MARCOS, T. LLOVET*, P. COLL* and T. JIMENEZ DE ANTA \\ Servei de Microbiologia, Hospital Clinic, Facultat de Medicina, Universitat de Barcelona, Villarroel 170, 08036 \\ Barcelona and * Departament de Genetica i Microbiologia, Universitat Autonoma de Barcelona, Avda. Sant Antoni \\ M. Claret 167, 08025 Barcelona, Spain
}

\begin{abstract}
Summary. Arbitrarily primed polymerase chain reaction (AP-PCR) and ribotyping were compared in an investigation of an outbreak of Acinetobacter baumannii infections. Twentyfive clinical isolates shown previously by other criteria to belong to two different groups, and nine randomly selected $A$. baumannii clinical isolates from other hospitals were investigated. Among the strains analysed, nine different $E c o$ RI rRNA gene restriction pattern fingerprints were observed. While similarity was detected between strains of the same group, these fingerprints differed clearly between the two $A$. baumannii groups defined in the outbreak. Two of the nine strains selected randomly had the same ribotype as those strains involved in the outbreak, whereas the remaining seven strains each had a different ribotype. When the strains were tested by AP-PCR with $0 \cdot 25,0 \cdot 5$ or $1 \mu \mathrm{M}$ of M13 forward primer, 10 different profiles were obtained. However, 11 profiles were observed if two different primer concentrations $(0 \cdot 25$ and $1 \mu \mathrm{M})$ were used. It was concluded that ribotyping and AP-PCR exhibited a similar discriminatory power, although AP-PCR had the additional advantages of speed and simplicity.
\end{abstract}

\section{Introduction}

Acinetobacter baumannii is an established cause of nosocomial infection, mainly in intensive care units. ${ }^{1-6}$ Numerous methods have been proposed for typing $A$. baumannii strains. Antibiograms and commercially available biotyping schemes such as the API 20NE system have been used, but published opinions on their reliability vary and they appear to lack sensitivity. ${ }^{7}$ Phage typing, bacteriocin typing and serotyping are available in only a few reference laboratories. ${ }^{8-10}$ Fingerprinting either of whole-cell proteins or cell-envelope proteins by SDS-PAGE has been used successfully, ${ }^{11-14}$ and several studies ${ }^{6,15,16}$ have shown plasmid profiling to be useful for typing, despite the fact that c. $28 \%$ of strains isolated do not carry plasmids. DNA restriction fragment length polymorphisms (RFLPs) on pulsed-field gels and ribotyping have also been used as epidemiological markers. ${ }^{17-20}$ These methods are highly discriminatory and reproducible, but their use has been limited because of

Received 3 March 1994; accepted 13 April 1994. Correspondence should be sent to Dr J. Vila. the lengthy experimental procedures involved. More recently, the polymerase chain reaction (PCR) has been used in conjunction with primers for the core sequence of phage $M 13^{21}$ or enterobacterial repetitive intergenic consensus sequences ${ }^{22}$ to study $A$. baumannii isolates from an outbreak in a hospital. The results seem promising, as all strains involved in the outbreak studied had the same pattern, but further studies are needed to confirm the sensitivity and reproducibility of the method and its value as an epidemiological tool. As discrimination can be optimised by the use of additional primers or modified assay conditions, or both, the purpose of this study was to compare arbitrarily primed PCR (AP-PCR), with two different primers and sets of amplification conditions, with ribotyping for delineating outbreaks of nosocomial infection caused by $A$. baumannii.

\section{Materials and methods}

\section{Bacterial strains}

In total, 34 isolates were analysed; 25 had been divided previously into two groups (13 strains in the 
A

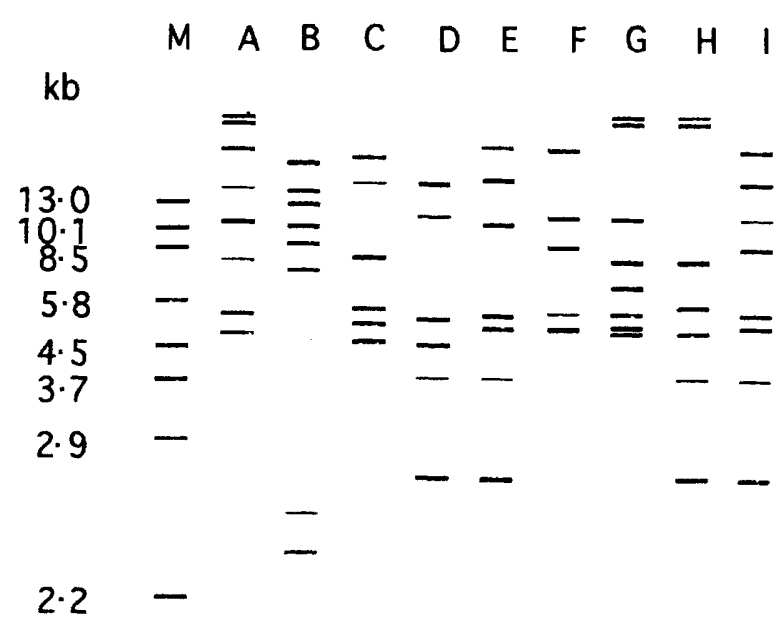

B

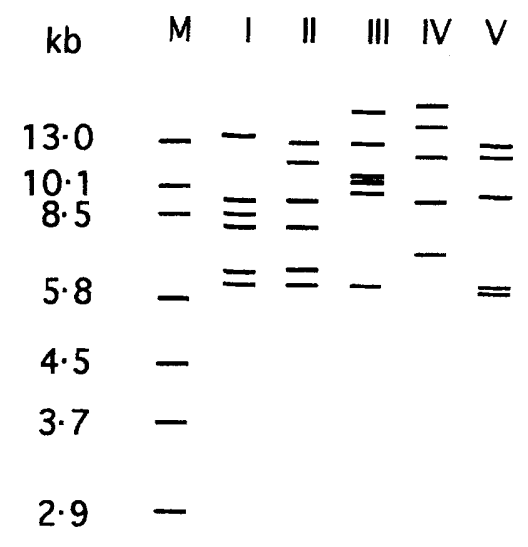

Fig. 1. Schematic representation of the ribotypes of $A$. baumannii. A, ribotypes obtained from DNA digested with $E c o$ RI. Lane A, strain 54 ; B, 68; C, 74; D, 77 (representative of group I involved in the outbreak) and 183; E, 88 (representative of group II involved in the outbreak) and $201 ; \mathbf{F}, 6 ; \mathbf{G}, 92 ; \mathbf{H}, 198 ; \mathbf{I}, 31$. B, ribotypes obtained from DNA digested with ClaI. Lane I, strains 6, 31, 77, 183, and 198; II, 88 and $201 ;$ III, $54 ;$ IV , $68 ; \mathbf{V}, 92$. Lane $\mathbf{M}$ indicates positions of DNA molecular size markers.

first group and 12 strains in the second group) involved in an outbreak in an intensive care unit, ${ }^{6}$ while the remaining nine strains (strain nos. 6, 31, 54, 68, 74, 92, 183,198 and 201) were collected from other Spanish hospitals. Identification of $A$. baumannii was based on standard biochemical reactions and the criteria of Bouvet and Grimont. ${ }^{23}$

\section{Isolation of chromosomal DNA}

The cell pellet from a 10-ml overnight Luria-Bertani broth culture was resuspended in $400 \mu \mathrm{l}$ of $10 \mathrm{~mm}$ Tris$\mathrm{HCl}, \mathrm{pH} 7.5,1 \mathrm{~mm}$ EDTA, mixed with $40 \mu \mathrm{l}$ of lysozyme $10 \mathrm{mg} / \mathrm{ml}$, and held at $-20^{\circ} \mathrm{C}$ for $30 \mathrm{~min}$. The bacterial cells were then lysed by gentle mixing with $80 \mu \mathrm{l}$ of lysis buffer $(50 \mathrm{~mm}$ Tris- $\mathrm{HCl}, \mathrm{pH} 7 \cdot 5$, $400 \mathrm{~mm}$ EDTA, SDS $0.5 \% \mathrm{w} / \mathrm{v}$, proteinase $\mathrm{K}$ $1 \mathrm{mg} / \mathrm{ml})$ at $60^{\circ} \mathrm{C}$ until the lysate cleared $(c .45 \mathrm{~min})$. The DNA was extracted three times with 1 volume of phenol:chloroform:isoamyl alcohol $(25: 24: 1)$ and twice with chloroform:isoamyl alcohol (24:1), and was then precipitated by adding 1 volume of cold ethanol $96 \% \mathrm{v} / \mathrm{v}$ and holding at $-20^{\circ} \mathrm{C}$ for at least $30 \mathrm{~min}$. After washing once with ethanol $70 \% \mathrm{v} / \mathrm{v}$, the purified DNA was pelleted by centrifugation, dried and resuspended in $10 \mathrm{~mm}$ Tris- $\mathrm{HCl}, \mathrm{pH} 8.0,1 \mathrm{~mm}$ EDTA before quantifying spectrophotometrically at $\mathrm{OD}_{260}$.

\section{$D N A$ restriction endonuclease digestion}

Purified DNA $(6-8 \mu \mathrm{g})$ was digested with $25 \mathrm{U}$ of EcoRI or ClaI overnight as recommended by the manufacturer (Pharmacia). The resulting DNA fragments were separated by horizontal electrophoresis in agarose $0.6 \% \mathrm{w} / \mathrm{v}$ gels in $89 \mathrm{~mm}$ Tris-borate, $\mathrm{pH} 8.5$, $1 \mathrm{mM}$ EDTA run at $35 \mathrm{~V}$ for $18 \mathrm{~h}$. After electrophoresis, the gels were stained with ethidium bromide $0.5 \mathrm{mg} / \mathrm{L}$ and visualised under UV illumination
$(230 \mathrm{~nm})$. Xenorhabdus strain 278 (obtained from P. A. D. Grimont, Paris, France) chromosomal DNA digested with $E c o$ RI was used on each gel as a molecular size standard.

\section{Southern blotting}

DNA in gels was depurinated in $0.25 \mathrm{M} \mathrm{HCl}$ for $10 \mathrm{~min}$, denatured in $0.5 \mathrm{M} \mathrm{NaOH}, 1.5 \mathrm{M} \mathrm{NaCl}$ for $30 \mathrm{~min}$ with gentle shaking, and neutralised in $1.5 \mathrm{M}$ $\mathrm{NaCl}, 1$ м Tris- $\mathrm{HCl}, \mathrm{pH} 8 \cdot 0$, for 30 min with gentle shaking. The fragments were transferred to a nylon membrane (Hybond-N, Amersham) with a Hybaid vacuum blotter, $10 \times \mathrm{SSC}(1 \times \mathrm{SSC}$ is $0.15 \mathrm{M} \mathrm{NaCl}$, $0.015 \mathrm{~m}$ trisodium citrate, $\mathrm{pH} \mathrm{7.0)}$ as the transfer solution and a vacuum time of $2 \mathrm{~h}$. The membranes were washed once in $2 \times$ SSC, air-dried and crosslinked under UV light for $3 \mathrm{~min}$.

\section{Ribotyping}

Pre-hybridisation, hybridisation with acetylaminofluorene-labelled rRNA from Escherichia coli (Eurogentec, Brussels, Belgium) and subsequent detection were as recommended by Eurogentec. Briefly, the nylon membranes were pre-hybridised at $65^{\circ} \mathrm{C}$ for $1 \mathrm{~h}$ in a solution comprising $20 \times \mathrm{SSC}, \quad 50 \times \mathrm{FPG}$ $(50 \times \mathrm{FPG}$ is Ficoll $4001 \% \mathrm{w} / \mathrm{v}$, polyvinylpyrrolidone $1 \% \mathrm{w} / \mathrm{v}$, glycine $1 \% \mathrm{w} / \mathrm{v}$ ) and sheared denatured herring sperm DNA $100 \mu \mathrm{g} / \mathrm{ml}$. The membranes were hybridised at $65^{\circ} \mathrm{C}$ overnight in a solution containing $2 \times \mathrm{SSC}, 1 \times \mathrm{FPG}, 25 \mathrm{mM} \mathrm{KH}_{2} \mathrm{PO}_{4}, \mathrm{pH} 8.0,2 \mathrm{~mm}$ EDTA, pH 8.0 , SDS $0.5 \% \mathrm{w} / \mathrm{v}$, freshly denatured sheared herring sperm DNA $100 \mu \mathrm{g} / \mathrm{ml}$ and heatdenatured acetylaminofluorene-labelled rRNA $0.5 \mu \mathrm{g} / \mathrm{ml}$. After hybridisation, the nylon membranes were washed three times in $2 \times \operatorname{SSC}$. SDS $0.1 \% \mathrm{w} / \mathrm{v}$ and once in $2 \times \mathrm{SSC}$. The hybridisation reactions were 
A

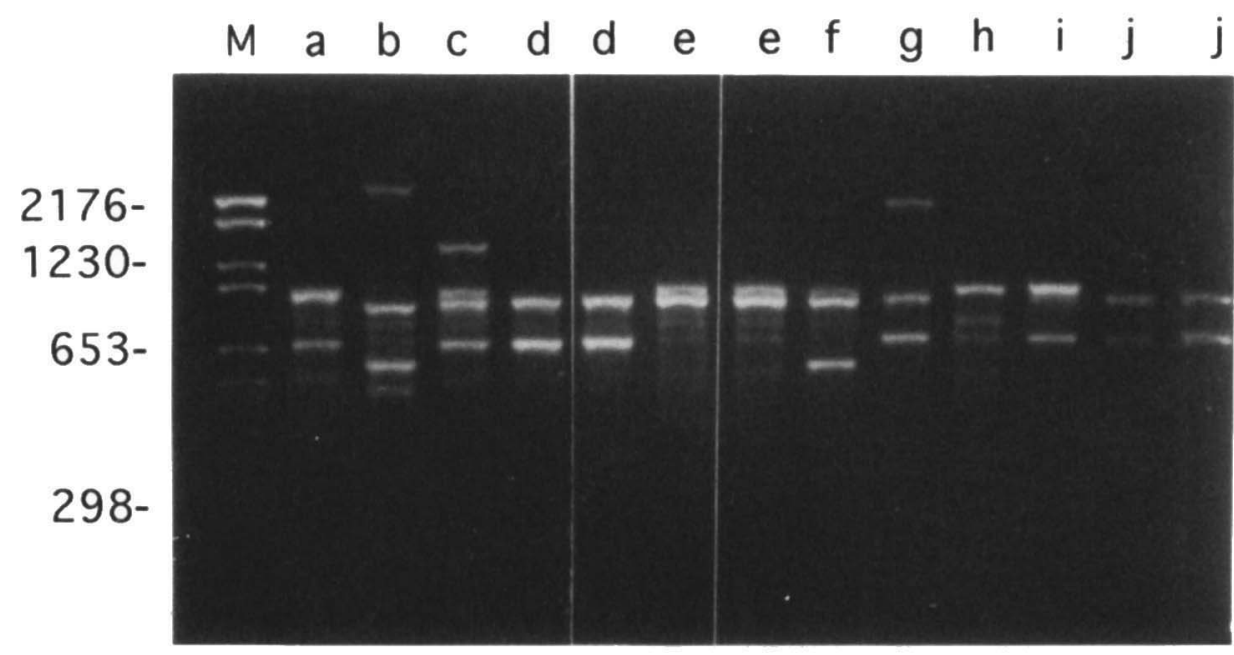

B

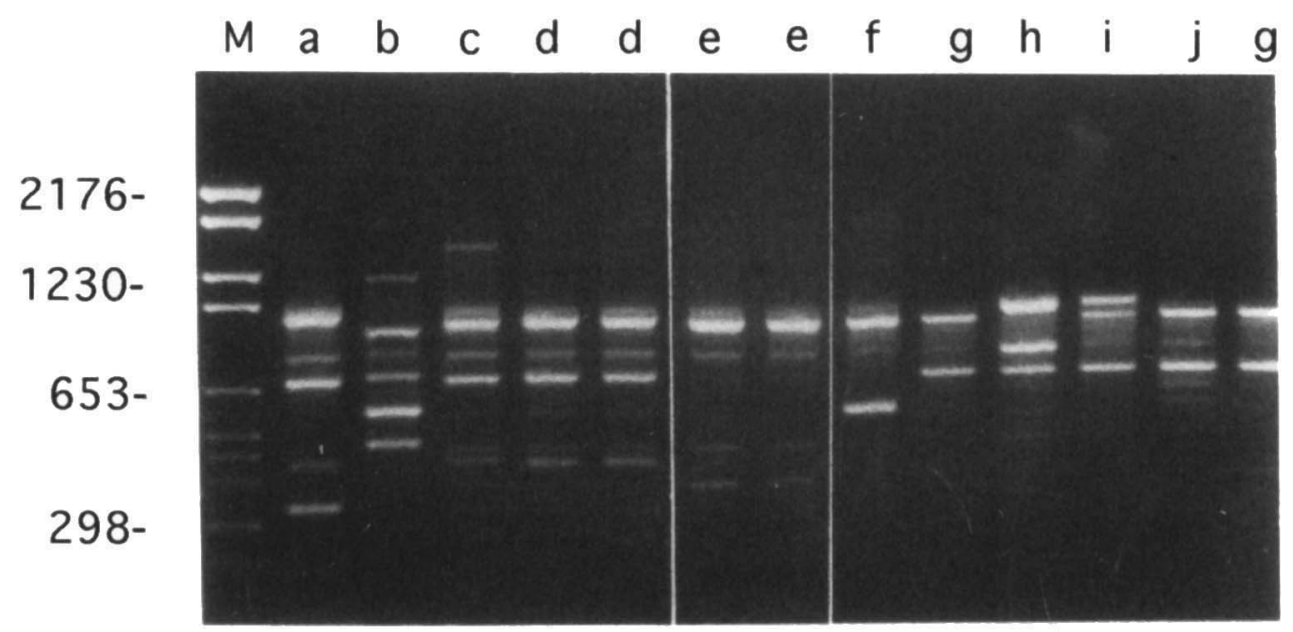

C

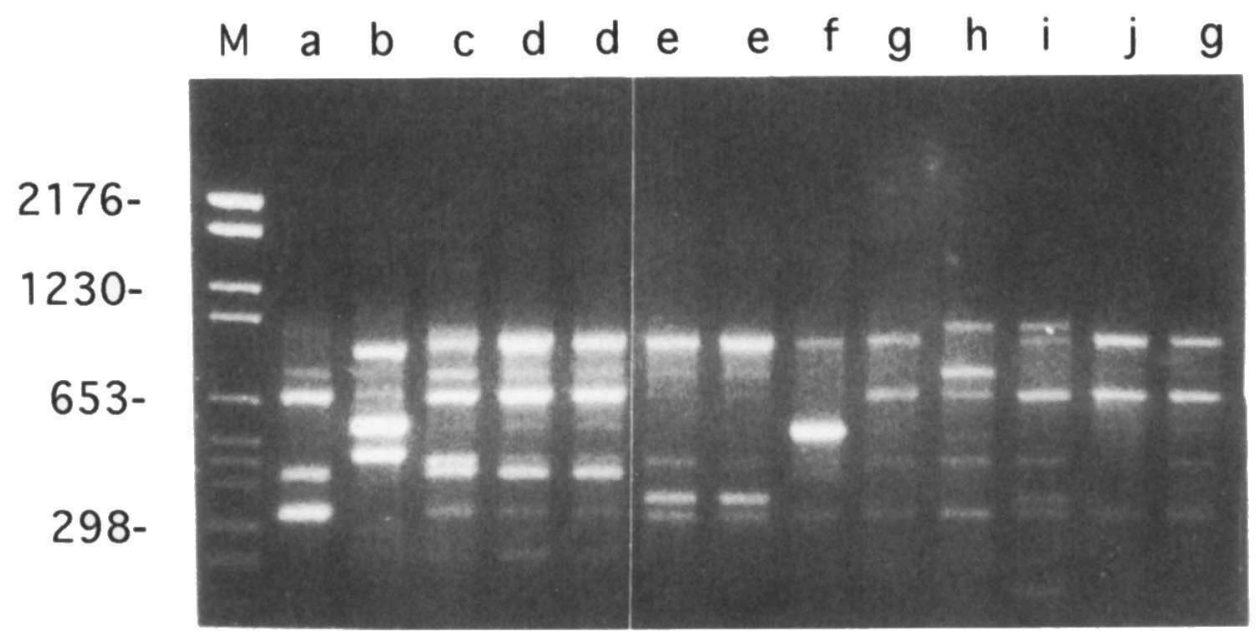

Fig. 2. AP-PCR analysis of $A$. baumannii strains with $\mathrm{A}, 0.25 \mu \mathrm{M} ; \mathbf{B}, 0.5 \mu \mathrm{M} ;$ or $\mathbf{C}, 1 \mu \mathrm{M}$ of M13 forward primer and temperature profile 1. Lane a, strain $54 ; \mathbf{b}, 68 ; \mathbf{c}, 74 ; \mathbf{d}, 77$ and 79 (representative of group I involved in the outbreak); e, 88 and 93 (representative of group II involved in the outbreak); $\mathbf{f}, 6 ; \mathbf{g}, 92 ; \mathbf{h}, 201 ; \mathbf{i}, 198 ; \mathbf{j}, 31$. The right-hand lane in each panel (labelled "j", "g" and "g", respectively) corresponds to strain 183. Lane M, DNA molecular size markers. 
visualised colorimetrically in an immunoenzymic reaction with nitroblue-tetrazolium, 5-bromo-4-chloro-3indolyl-phosphate and alkaline phosphatase-labelled anti-acetylaminofluorene antibodies (Eurogentec).

\section{$A P-P C R$ reactions}

These were performed as follows: one-half of a colony grown on MacConkey agar was resuspended in $25 \mu \mathrm{l}$ of sterile distilled water and boiled for $10 \mathrm{~min}$. After a short centrifugation step at $15000 \mathrm{~g}, 25 \mu \mathrm{l}$ of a reaction mixture containing $20 \mathrm{mM}$ Tris- $\mathrm{HCl}, \mathrm{pH} 8.8$, $100 \mathrm{~mm}$ potassium chloride, $3.0 \mathrm{~mm}$ magnesium chloride, gelatin $0.1 \% \mathrm{w} / \mathrm{v}, 400 \mu \mathrm{M}$ deoxynucleoside triphosphates and $0.5,1$, or $2 \mu \mathrm{M}$ of primer was added, together with $2.5 \mathrm{U}$ of $\mathrm{Taq}$ polymerase (Boehringer Mannheim). The primers used were: $5^{\prime}$-GTT GTA AAA CGA CGG CCA GT-3' (M13 forward amplification primer) and 5'-AAC AGC TAT GAC CAT GAT TA-3' (M13 reverse amplification primer), obtained from MedProbe, Oslo, Norway. Each reaction was overlaid with oil and amplified with one of two different temperature profiles: (i) two cycles of $94^{\circ} \mathrm{C}$ for $5 \mathrm{~min}, 40^{\circ} \mathrm{C}$ for $5 \mathrm{~min}$ and $72^{\circ} \mathrm{C}$ for $5 \mathrm{~min}$, followed by $40 \mathrm{high}$ stringency cycles of $94^{\circ} \mathrm{C}$ for $1 \mathrm{~min}, 60^{\circ} \mathrm{C}$ for $1 \mathrm{~min}$ and $72^{\circ} \mathrm{C}$ for $2 \mathrm{~min}$; (ii) 45 cycles of $94^{\circ} \mathrm{C}$ for $1 \mathrm{~min}, 36^{\circ} \mathrm{C}$ for $1 \mathrm{~min}$ and $72^{\circ} \mathrm{C}$ for $2 \mathrm{~min}$. Amplification was performed in a DNA thermal cycler Model 480 (Perkin-Elmer Cetus). Amplified DNA products were resolved by electrophoresis in agarose $2 \% \mathrm{w} / \mathrm{v}$ gels containing ethidium bromide $0.5 \mathrm{mg} / \mathrm{L}$.

\section{Results}

\section{Ribotyping}

$C l a \mathrm{I}$ and $E c o$ RI were compared for their ability to provide clear and discriminative ribotypes of $A$. baumannii. ClaI generated poorly discriminative profiles with a small number of rDNA fragments; however, five different ribotypes (designated I-V) of 5-6 bands were distinguished (fig. 1B), comprising bands between 6.0 and $15 \mathrm{~kb}$ in size. In contrast, among the $34 \mathrm{~A}$. baumannii strains analysed, nine different $E c o$ RI

Table. Comparison of results obtained by ribotyping and AP-PCR for 34 strains of $A$. baumannii

\begin{tabular}{|c|c|c|c|c|c|c|c|c|c|c|}
\hline \multirow{2}{*}{ Ribotype } & \multicolumn{10}{|c|}{$\begin{array}{l}\text { Number of strains with the } \\
\text { AP-PCR profile indicated* }\end{array}$} \\
\hline & $\mathrm{a}$ & b & $\mathrm{c}$ & $\mathrm{d}$ & $\mathrm{e}$ & $\mathrm{f}$ & $\mathrm{g}$ & $\mathrm{h}$ & $\mathrm{i}$ & $\mathrm{j}$ \\
\hline A & 1 & 0 & 0 & 0 & 0 & 0 & 0 & 0 & 0 & 0 \\
\hline B & 0 & 1 & 0 & 0 & 0 & 0 & 0 & 0 & 0 & 0 \\
\hline $\mathrm{C}$ & 0 & 0 & 1 & 0 & 0 & 0 & 0 & 0 & 0 & 0 \\
\hline D & 0 & 0 & 0 & 12 & 0 & 0 & 1 & 0 & 0 & 0 \\
\hline $\mathrm{E}$ & 0 & 0 & 0 & 0 & 13 & 0 & 0 & 1 & 0 & 0 \\
\hline $\mathrm{F}$ & 0 & 0 & 0 & 0 & 0 & 1 & 0 & 0 & 0 & 0 \\
\hline $\mathrm{G}$ & 0 & 0 & 0 & 0 & 0 & 0 & 1 & 0 & 0 & 0 \\
\hline $\mathrm{H}$ & 0 & 0 & 0 & 0 & 0 & 0 & 0 & 0 & 1 & 0 \\
\hline I & 0 & 0 & 0 & 0 & 0 & 0 & 0 & 0 & 0 & 1 \\
\hline Total & 1 & 1 & 1 & 12 & 13 & 1 & 2 & 1 & 1 & 1 \\
\hline
\end{tabular}

*AP-PCR profiles generated with a primer concentration of $1 \mu \mathrm{M}$.
rRNA gene restriction patterns (designated A-I; fig. 1A) were distinguished. The chromosomal fragments containing rRNA genes ranged in size from $2 \cdot 5-18 \mathrm{~kb}$, with patterns comprising 5-8 bands. The patterns differed by the presence or absence of at least two bands; exceptions were ribotypes $\mathrm{E}$ and $\mathrm{I}$, which appeared to be very similar and differed in only a single c. $8 \cdot 5-\mathrm{kb}$ band. Ribotyping revealed that the outbreak isolates (e.g., strain no. 77-ribotype D-and strain no. 41-ribotype E) and two isolates from other hospitals (strain no. 183-ribotype D-and strain no. 201-ribotype E) shared the same ribotype patterns. If the results obtained with both enzymes were combined, the discriminatory power was not increased.

\section{AP-PCR fingerprinting}

The 34 A. baumannii isolates were subjected to PCR in conjunction with M13 forward primer, M13 reverse primer, or with both. The results obtained with M13 forward primer alone or both primers together were identical, whereas M13 reverse primer produced poorer discrimination when used alone (data not shown). Identical results were obtained with M13 forward primer and either of the two temperature profiles, but a decrease in the primer concentration resulted in an overall synthesis of longer amplicons; smaller fragments tended to disappear from the DNA banding patterns. Ten different banding patterns (designated a-j; fig. 2) were distinguished, comprising 2-7 DNA fragments of $0 \cdot 1-2 \cdot 2 \mathrm{~kb}$ in size. PCR profiles of strains involved in the outbreak showed the same pattern for strains of the same group, but were clearly different for strains belonging to different groups. Eight of the nine strains collected from other hospitals had a pattern different from the strains involved in the outbreak. The remaining strain (no. 183) had the same AP-PCR pattern as strain no. 92 with a primer concentration of $1 \mu \mathrm{M}$ (pattern g) or $0.25 \mu \mathrm{M}$ (pattern j).

The small differences in fingerprinting patterns caused by minor DNA fragments were demonstrated repeatedly. The reproducibility of the technique was determined by testing three strains five times and the remaining strains four times. However, a decrease in the intensity of the larger bands was observed occasionally. The results were reproducible from one assay to another. The same profiles were obtained with purified DNA and DNA obtained direct from a boiled colony suspension (data not shown).

\section{Correlation between ribotyping and AP-PCR}

The ribotyping results showed good agreement with the results obtained by AP-PCR (table). While similarity between strains of the same group was detected by ribotyping and AP-PCR, these techniques clearly differentiated between the $A$. baumannii groups defined previously in the outbreak. Similar results were obtained with the remaining strains of the outbreak not shown in figs. 1 and 2. Ribotypes A, B, C, $\mathrm{F}, \mathrm{H}$ and I each correlated with a different AP-PCR 
profile. No correlation between the two techniques was observed for two strains (nos. 201 and 183). Strain no. 201 had a different AP-PCR pattern to the other strains studied, but had the same ribotyping pattern as one of the groups involved in the outbreak (ribotype E), whereas strain no. 183 had a similar AP-PCR pattern to strain no. 201 (pattern g) but a different ribotype (D). Other epidemiological tools (analysis of chromosomal DNA by pulsed-field gel electrophoresis, plasmidanalysis orantibiograms)also demonstrated clearly that these strains were independent from the other strains analysed (unpublished results).

\section{Discussion}

Various genotypic markers have been used for epidemiological typing of $A$. baumannii to investigate relationships between clinical isolates. In addition to the ability to discriminate strains within a species, ease of performance and interpretation of the results and the availability of reagents is of major importance in a clinical laboratory. The objective of this study was to investigate the value of AP-PCR in comparison with ribotyping for an epidemiological investigation. Clinical isolates from an outbreak defined previously, ${ }^{6}$ in which two different groups of strains were involved, and randomly selected clinical isolates of $A$. baumannii from other hospitals were used to assess the discriminative power of AP-PCR. The latter isolates were presumably derived from sporadic cases of infection.

Ribotyping with labelled E. coli rRNA used to probe the ubiquitous and polymorphic rRNA loci ${ }^{24,25}$ has acquired wide acceptance as a powerful epidemiological tool. Ribotyping has several advantages, including patterns which are easy to interpret because of the limited number of hybridised fragments, and ribotypes that are stable and reproducible after continued subculture. The importance of the choice of enzyme for ribotyping has been emphasised elsewhere. In the present study, EcoRI provided more fragments and a greater diversity in rDNA patterns than ClaI. This contrasted with the data of Grimont et al.$^{26}$ who found that $\mathrm{Cla}$ I generated 13 different patterns from $20 \mathrm{~A}$. baumannii strains. Gerner-Smidt ${ }^{19}$ analysed 70 strains in the $A$. calcoaceticus $-A$. baumannii complex after digestion with EcoRI, ClaI and SalI, and observed good discrimination by combining the results obtained with all three enzymes, whereas Dijkshoorn et al. ${ }^{18}$

\section{References}

1. Castle M, Tenney JH, Weinstein MP, Eickhoff TC. Outbreak of a multiply resistant Acinetobacter in a surgical intensive care unit: epidemiology and control. Heart Lung 1978; 7 : 641-644.

2. Sherertz RJ, Sullivan ML. An outbreak of infections with Acinetobacter calcoaceticus in burn patients: contamination of patients' mattresses. J Infect Dis 1985; 151: 252-258.

3. Stone JW, Das BC. Investigation of an outbreak of infection with Acinetobacter calcoaceticus in a special care baby unit. $J$ Hosp Infect 1986; 7: 42-48. showed acceptable strain differentiation by ribotyping with $E c o$ RI and $H i n d I I I$, with results similar to those obtained by analysis of cell envelope protein profiles. In the present study, two strains selected randomly from other hospitals had the same ribotype as the strains involved in the outbreak. However, further investigation by pulsed-field electrophoresis, plasmid analysis and antibiograms showed that these strains differed clearly from each other and from the rest of the strains analysed.

Ribotyping is a labour-intensive process and requires several days for completion. The AP-PCR method $^{27}$ is based on the amplification of random DNA fragments with a single primer of arbitrary nucleotide sequence. Vassart et al..$^{28}$ found that a DNA sequence from the genome of bacteriophage M13 could be used to reveal hypervariable mini-satellite sequences in man and bovines, and primers derived from M13 have been used to study DNA polymorphisms in various animals, plants and microorganisms. ${ }^{29}$ Graser et al. ${ }^{21}$ amplified DNA from $A$. baumannii with the core sequence of the M13 phage as a single primer. The discriminative power was similar to that of pulsed-field gel electrophoresis if a primer concentration of $25 \mu \mathrm{M}$ was combined with different amplification conditions to those used in the present study, in which a decrease in band intensity was observed with a primer concentration in excess of $10 \mu \mathrm{M}$, and higher discriminatory power was obtained with primer concentrations of 0.25 or $1 \mu \mathrm{M}$. Recently, Struelens et al. ${ }^{22}$ evaluated PCR-mediated fingerprinting with directed primer sets designed to amplify chromosomal regions lying between repetitive multicopy elements that are dispersed widely in eubacterial genomes, e.g., the 126-bp enterobacterial repetitive intergenic consensus (ERIC) sequence. With this set of primers, agreement was observed between the PCR method and the results of macrorestriction analysis by pulsed-field gel electrophoresis when investigating an outbreak of infections caused by A. baumannii. In the present study, ribotypes $\mathrm{A}, \mathrm{B}, \mathrm{C}, \mathrm{F}, \mathrm{H}$ and I each correlated with a different AP-PCR profile, and it was concluded that AP-PCR was a simple and rapid method with a high discriminatory power which can be used as a complementary technique for the epidemiological study of $A$. baumannii clinical isolates.

This work was supported by grant PB88/0206 from DGICYTSpain to J.V. and grant 93/0693 from FISss-Spain to P.C.

4. Hartstein AI, Rashad AL, Liebler JM et al. Multiple intensive care unit outbreak of Acinetobacter calcoaceticus subspecies anitratus respiratory infection and colonization associated with contaminated, reusable ventilator circuits and resuscitation bags. Am J Med 1988; 85: 624-631.

5. Cefai C, Richards J, Gould FK, McPeake P. An outbreak of Acinetobacter respiratory tract infection resulting from incomplete disinfection of ventilatory equipment. $J$ Hosp Infect 1990; 15: 177-182.

6. Vila J, Almela M, Jimenez de Anta MT. Laboratory investigation of hospital outbreak caused by two different multiresistant Acinetobacter calcoaceticus subsp. anitratus strains. J Clin Microbiol 1989; 27: 1086-1089. 
7. Towner KJ, Chopade BA. Biotyping of Acinetobacter calcoaceticus using the API 20NE system. J Hosp Infect 1987; 10: $145-151$.

8. Andrews HJ. Acinetobacter bacteriocin typing. $J$ Hosp Infect 1986; 7: 169-175.

9. Traub WH. Acinetobacter baumannii serotyping for delineation of outbreaks of nosocomial cross-infection. J Clin Microbiol 1989; 27 : 2713-2716.

10. Vieu JF, Bergogne-Bérézin E, Joly ML, Berthelot G, Fichelle A, Prevost C. Epidémiologie d'Acinetobacter calcoaceticus. Nouv Presse Med 1980; 9: 3551-3552.

11. Alexander M, Ismail F, Jackman PJH, Noble WC. Fingerprinting Acinetobacter strains from clinical sources by numerical analysis of electrophoretic patterns. $J \mathrm{Med}$ Microbiol 1984; 18: 55-64.

12. Dijkshoorn L, Michel MF, Degener JE. Cell envelope protein profiles of Acinetobacter calcoaceticus strains isolated in hospitals. J Med Microbiol 1987; 23: 313-319.

13. Dijkshoorn L, van Vianen W, Degener JE, Michel MF. Typing of Acinetobacter calcoaceticus strains isolated from hospital patients by cell envelope protein profiles. Epidemiol Infect 1987; 99: 659-667.

14. Vila J, Canales MA, Marcos MA, Gomez-Lus R, Jimenez de Anta MT. Molecular epidemiological analysis of nosocomial Acinetobacter baumannii isolates. In: Towner $\mathrm{KJ}$, Bergogne-Bérézin E, Fewson CA (eds) The biology of Acinetobacter: taxonomy, clinical importance, molecular biology, physiology, industrial relevance. New York, Plenum Press. 1991: 69-76.

15. Gerner-Smidt P. Frequency of plasmids in strains of Acinetobacter calcoaceticus. J Hosp Infect 1989; 14: 23-28.

16. Kropec A, Hubner J, Daschner FD. Comparison of three typing methods in hospital outbreaks of Acinetobacter calcoaceticus infection. J Hosp Infect 1991; 23: 133-141.

17. Allardet-Servent A, Bouziges N, Carles-Nurit MJ, Bourg G, Gouby A, Ramuz M. Use of low-frequency-cleavage restriction endonucleases for DNA analysis in epidemiological investigation of nosocomial bacterial infections. $J$ Clin Microbiol 1989; 27: 2057-2061.

18. Dijkshoorn L, Aucken HM, Gerner-Smidt P, Kaufmann ME, Ursing J, Pitt TL. Correlation of typing methods for Acinetobacter isolates from hospital outbreaks. $J$ Clin Microbiol 1993; 31 : 702-705.

19. Gerner-Smidt P. Ribotyping of the Acinetobacter calcoaceticus-
Acinetobacter baumannii complex. J Clin Microbiol 1992; 30: 2680-2685.

20. Gouby A, Charles-Nurit MJ, Bouziges N, Bourg G, Mesnard $\mathrm{R}$, Bouvet PJM. Use of pulsed-field gel electrophoresis for investigation of hospital outbreaks of Acinetobacter baumannii. J Clin Microbiol 1992; 30: 1588-1591.

21. Graser Y, Klare I, Halle E et al. Epidemiological study of an Acinetobacter baumannii outbreak by using polymerase chain reaction fingerprinting. J Clin Microbiol 1993; 31: 2417-2420.

22. Struelens MJ, Carlier E, Maes N, Serruys E, Quint WG, van Belkum A. Nosocomial colonization and infection with multiresistant Acinetobacter baumannii: outbreak delineation using DNA macrorestriction analysis and PCRfingerprinting. $J$ Hosp Infect $1993 ; 25$; 15-32.

23. Bouvet PJM, Grimont PAD. Taxonomy of the genus Acinetobacter with the recognition of Acinetobacter baumannii sp. nov., Acinetobacter haemolyticus sp. nov., Acinetobacter johnsonii sp. nov., and Acinetobacter junii sp. nov. and emended descriptions of Acinetobacter calcoaceticus and Acinetobacter lwoffii. Int $J$ Syst Bacteriol 1986; 36: 228-240.

24. Grimont F, Grimont PAD. Ribosomal ribonucleic acid gene restriction patterns as potential taxonomic tools. Ann Inst Pasteur Microbiol 1986; 137B : 165-175.

25. Hadorn K, Lenz W, Kayser FH, Shalit I, Krasemann C. Use of a ribosomal RNA gene probe for the epidemiological study of methicillin and ciprofloxacin resistant Staphylococcus aureus. Eur J Clin Microbiol Infect Dis 1990; 9: 649-653.

26. Grimont PAD, Bouvet PJM. Taxonomy of Acinetobacter. In: Towner KJ, Bergogne-Bérézin E, Fewson CA (eds) The biology of Acinetobacter: taxonomy, clinical importance, molecular biology, physiology, industrial relevance. New York, Plenum Press. 1991: 25-36.

27. Welsh J, McClelland M. Fingerprinting genomes using PCR with arbitrary primers. Nucleic Acids Res 1990; 18: 7213-7218.

28. Vassart G, Georges M, Monsieur R, Brocas H, Lequarre AS, Christophe D. Sequence in M13 phage detects hypervariable satellites in human and animal DNA. Science $1987 ; 235$ : 683-684.

29. Ryskov AP, Jincharadze AG, Prosnyak MI, Ivanov PL, Limborska SA. M13 phage DNA as a universal marker for DNA fingerprinting of animals, plants and microorganisms. FEBS Lett 1988; 233: 388-392. 